\title{
Elevated flow rate during cardiopulmonary bypass is associated with fluid accumulation
}

Oddbjørn Haugen, MD, ${ }^{a}$ Marit Farstad, MD, PhD, ${ }^{c}$ Venny Kvalheim, MD, ${ }^{\text {b }}$ Olav Bøe, DDS, MSc, ${ }^{d}$ and Paul Husby, MD, $\mathrm{PhD}^{\mathrm{c}}$

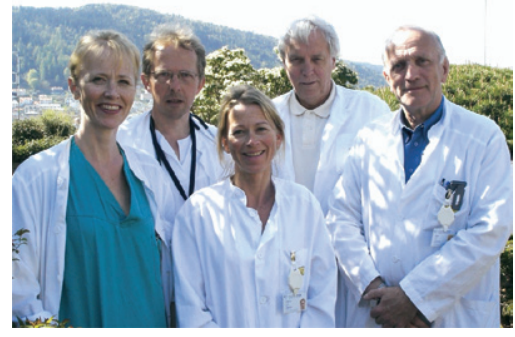

Drs Kvalheim, Haugen, Farstad, Bøe, and Husby (left to right)
From the Department of Anesthesia and Intensive Care $^{\mathrm{a}}$ and the Section for Thoracic Surgery, Department of Heart Disease, ${ }^{\text {b }}$ Haukeland University Hospital; the Surgical Research Laboratory, Department of Surgical Sciences ${ }^{c}$; and the Department of Oral Science, Dental Research, ${ }^{\mathrm{d}}$ University of Bergen, Bergen, Norway.

This study was financially supported by The Western Norway Regional Health Authority, The Norwegian Council on Cardiovascular Diseases, Faculty of Medicine, University of Bergen, and The Frank Mohn Foundation, Norway.

Received for publication Feb 13, 2007; revisions received March 29, 2007; accepted for publication April 26, 2007.

Address for reprints: Paul Husby, MD, $\mathrm{PhD}$, Professor, Department of Surgical Sciences, University of Bergen, Haukeland University Hospital, N-5021 Bergen/Norway. Phone: $(+47) 55976850$ (secretary) Fax: (+47) 559768 98. E-mail: paul. husby@kir.uib.no

J Thorac Cardiovasc Surg 2007;134:587-93

$0022-5223 / \$ 32.00$

Copyright (C) 2007 by The American Association for Thoracic Surgery

doi:10.1016/j.jtcvs.2007.04.040
Objective: High flow rates during cardiopulmonary bypass are assumed to increase fluid accumulation. This study aimed to determine whether two different flow rates during cardiopulmonary bypass alter the intraoperative fluid balance and extravasation rate.

Methods: Sixteen pigs underwent 60 minutes of normothermic bypass, followed by 90 minutes of hypothermic bypass. A high-flow group (HF group, $\mathrm{n}=8$ ) had a cardiopulmonary bypass flow rate of $110 \mathrm{~mL} \cdot \mathrm{kg}^{-1} \cdot \mathrm{min}^{-1}$ and a low-flow group (LF group, $\mathrm{n}=8$ ) had a rate of $80 \mathrm{~mL} \cdot \mathrm{kg}^{-1} \cdot \mathrm{min}^{-1}$. Blood chemistry, hemodynamic parameters, plasma and interstitial colloid osmotic pressure, net fluid balance, plasma volume, fluid extravasation rate, and total tissue water content were measured or calculated. Results are presented as mean (standard deviation).

Results: The average net fluid balance during cardiopulmonary bypass was 1.02 $(0.25)$ and $0.73(0.23) \mathrm{mL} \cdot \mathrm{kg}^{-1} \cdot \mathrm{min}^{-1}$ in the HF group and LF group, respectively $(P<.05)$. The average fluid extravasation rate was $0.98(0.22)$ and 0.77 $(0.22) \mathrm{mL} \cdot \mathrm{kg}^{-1} \cdot \mathrm{min}^{-1}$ in the HF group and the LF group $(P=.07)$. Total water content was higher in the kidneys $(P<.05)$ and tended to be higher in the lungs $(P=.05)$, liver $(P=.07)$, and brain $(P=.07)$ of the HF group than in those of the LF group. The between-group differences in net fluid balance and fluid extravasation rate were present during the first 30 minutes of normothermic cardiopulmonary bypass. Thereafter, the values stabilized and remained similar in the two groups. Plasma volume and systemic vascular resistance differed between the groups.

Conclusion: Cardiopulmonary bypass flow rate of $110 \mathrm{~mL} \cdot \mathrm{kg}^{-1} \cdot \mathrm{min}^{-1}$ was associated with higher positive net fluid balance and fluid extravasation rate than 80 $\mathrm{mL} \cdot \mathrm{kg}^{-1} \cdot \mathrm{min}^{-1}$. The effect was mainly observed in the initial phase of cardiopulmonary bypass.

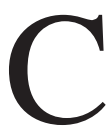

ardiopulmonary bypass $(\mathrm{CPB})$ is commonly associated with fluid accumulation and edema formation, mainly resulting from hemodilution by use of crystalloid prime. Highly positive intraoperative fluid balance during cardiac surgery was recently shown to be associated with adverse clinical outcome. ${ }^{1}$ Even though the causal relationship between fluid gain and postoperative morbidity is not clear, interventions aimed at reducing fluid accumulation by ultrafiltration or by administration of hypertonic-hyperoncotic fluids have improved morbidity after on-pump cardiac surgery. ${ }^{2,3}$

In recent animal studies we evaluated factors other than hemodilution that could be responsible for fluid retention and extravasation during CPB. Hypothermia was found to be an independent causal factor. ${ }^{4}$ Fluid extravasation during hypothermic CPB could be counteracted by use of iso-oncotic prime, ${ }^{5}$ whereas treatment with anti-inflammatory agents did not influence fluid shifts. ${ }^{6}$ 


\author{
Abbreviations and Acronyms \\ $\mathrm{COP}=$ colloid osmotic pressure \\ COPi $=$ colloid osmotic pressure in interstitial fluid \\ $\mathrm{COPp}=$ colloid osmotic pressure in plasma \\ $\mathrm{CPB}=$ cardiopulmonary bypass \\ $\mathrm{CVP}=$ central venous pressure \\ $\mathrm{HF}=$ high flow \\ $\mathrm{LF}=$ low flow \\ MAP $=$ mean arterial pressure \\ $\mathrm{PV}=$ plasma volume
}

The relationship between CPB flow rate and fluid balance is not well established. CPB flow rate could theoretically have an impact on fluid extravasation by affecting capillary hydrostatic pressure or capillary surface area or by altering the plasma volume (PV) and consequently the degree of hemodilution.

In the present study, we compared fluid balance and extravasation rates during normothermic and hypothermic CPB with two different perfusion flow rates. Prebypass cardiac output in anesthetized young pigs was known from previous studies. The CPB flow rates of the study groups were set above or below their assumed prebypass values. The experiments were performed with beating hearts, and left ventricles were vented to assure that all animals in each group had the same effective flow rate.

We hypothesized that a CPB flow rate of $110 \mathrm{~mL} \cdot \mathrm{kg}^{-1}$. $\mathrm{min}^{-1}$ would lead to a higher net fluid balance and fluid extravasation rate compared with a CPB flow rate of $80 \mathrm{~mL}$. $\mathrm{kg}^{-1} \cdot \min ^{-1}$.

\section{Materials and Methods}

\section{Animal Handling and Anesthesia}

Sixteen domestic pigs, aged 10 to 12 weeks, with a body weight of about $30 \mathrm{~kg}$ (Norwegian Landrace-Yorkshire hybrid), were studied. They received humane care in accordance with guidelines given by the Norwegian Animal Research Authority. All animals were acclimatized at the facility for a minimum of 3 days before the experiments. Food was withdrawn 8 to 12 hours before anesthesia. Water was available at all times.

Before anesthesia, the animals were premedicated with ketamine, diazepam, and atropine subcutaneously. Induction was performed by inhalation of isoflurane in oxygen and by an intravenous bolus of thiopentone before intubation of the trachea. Maintenance of anesthesia was achieved by inhalation of isoflurane in oxygenated air and a continuous infusion of midazolam, fentanyl, and pancuronium. Details of the anesthesia protocol have previously been described. ${ }^{7,8}$ Acetated Ringer solution was given as a continuous infusion with $5 \mathrm{~mL} \cdot \mathrm{kg}^{-1}$. $\mathrm{min}^{-1}$ from induction of anesthesia. Blood lost before $\mathrm{CPB}$ was replaced with acetated Ringer solution in volumes 3 times the blood loss volume.

\section{Surgical Preparation, CPB, and Monitoring}

With the animal in the supine position, a midline sternotomy was performed. Preparation for CPB was done after administration of heparin $9 \mathrm{mg} \cdot \mathrm{kg}^{-1}$. An $18 \mathrm{~F}$ aortic arch cannula (Medtronic Inc, Minneapolis, Minn) was inserted into the ascending aorta, a 17F vent catheter was introduced into the left ventricle (E061; Edwards Lifesciences, Irvine, Calif), and a 32F single venous return cannula (TF-034-L; Baxter Research Medical Inc, Midvale, Utah) was placed in the right atrium and connected to standard equipment for heart surgery. The CPB circuit with a membrane oxygenator (Quadrox, VHK4200; Jostra AG, Hirrlingen, Germany) was primed with acetated Ringer solution and the reservoir filled to a level of $300 \mathrm{~mL}$, resulting in a total volume of $1115 \mathrm{~mL}$ in the circuit. During CPB, the reservoir level was kept constant. Whenever it dropped below $300 \mathrm{~mL}$, extra acetated Ringer solution was added to restore the $300-\mathrm{mL}$ level. The difference in height between the right atrium and the reservoir was fixed $(73 \pm 3 \mathrm{~cm})$ during CPB. Free venous drainage was ensured by measurement of right atrial pressure and by visual inspection. Nonpulsatile flow was used.

Fluid-filled catheters (Secalone T, 18-gauge; BD Medical, Singapore) were introduced into the right femoral artery, femoral vein, and the right atrium for blood samples and pressure recordings. Cardiac output before $\mathrm{CPB}$ was measured by use of a thermodilution catheter (5F; Edwards Lifesciences) introduced into the wedging position in the pulmonary artery. Pulmonary arterial, pharyngeal, and rectal temperatures were recorded. Invasive pressures and temperatures were displayed on a monitor (HP-78353; Hewlett-Packard, Palo Alto, Calif).

A suprapubic urinary catheter was placed in the bladder through a midline laparotomy for urinary output monitoring. All surgical interventions were normally completed within 20 minutes.

During $\mathrm{CPB}$, blood loss to the surgical field was drained to the reservoir by suction.

Alpha-stat acid-base management was used.

\section{Study Protocol}

Sixteen animals were randomly allocated to a high-flow group (HF group, $\mathrm{n}=8$ ) or a low-flow group (LF group, $\mathrm{n}=8$ ). During CPB, the HF group had a CPB flow rate of $110 \mathrm{~mL} \cdot \mathrm{kg}^{-1} \cdot \mathrm{min}^{-1}$ and the LF group had a flow rate of $80 \mathrm{~mL} \cdot \mathrm{kg}^{-1} \cdot \mathrm{min}^{-1}$.

After induction of general anesthesia and surgical preparation, the animals were allowed stabilization for 60 minutes. CPB was then initiated and continued for 60 minutes with normothermia $\left(38^{\circ} \mathrm{C}\right)$ followed by 90 minutes with hypothermia $\left(28^{\circ} \mathrm{C}\right)$. During cooling, the water temperature in the $\mathrm{CPB}$ heat exchanger was set to $24^{\circ} \mathrm{C}$, resulting in a drop of core temperature to $28^{\circ} \mathrm{C}$ within 20 to 25 minutes. At the end of the experiments, the animals were killed with an intravenous bolus of $20 \mathrm{~mL}$ of saturated potassium chloride. Tissue samples were then collected in triplicate from most organs for determination of total tissue water content as previously described. ${ }^{5}$

\section{Colloid Osmotic Pressures and Blood Chemistry}

Colloid osmotic pressure (COP) was measured in plasma (COPp) and in interstitial fluid (COPi). Interstitial fluid was sampled by the wick technique. Multifilamentous nylon wicks were sewn into subcutaneous tissue of thoracoabdominal skin folds, left in situ for 
90 minutes, and then processed as previously described. ${ }^{9}$ Three sets of wicks were implanted to reflect the three phases of prebypass, normothermic $\mathrm{CPB}$, and hypothermic $\mathrm{CPB}$.

$\mathrm{COP}$ was measured with a colloid osmometer. The semipermeable membrane had a cutoff level at 10,000 Da (PM-10; Millipore Corporation, Bedford, Mass). Acetated Ringer solution was used in the reference chamber. ${ }^{9}$

The pressures were registered by a transducer (Gould-Statham; Spectramed Inc, Lewis Center, Ohio) connected to a recorder (Easy-Graph 240; Gould Electronics Inc, Eastlake, Ohio).

Every 30 minutes, blood samples were collected from the arterial line to determine COPp, hematocrit, acid-base parameters, blood glucose, serum osmolality, and the serum concentrations of albumin and protein. Analyses were conducted as recently described. $^{8}$

\section{PV, Net Fluid Balance, and Fluid Extravasation Rate}

Thirty minutes before CPB, erythrocyte volume of the animals was determined by the carbon monoxide method. ${ }^{10}$ On the basis of repeated measurements of hematocrit and blood loss during the experiments, new values for erythrocyte volume could be calculated every 30 minutes. Hence, PV at baseline and during CPB could easily be calculated.

The calculated PV was corrected by subtracting the volume of the extracorporeal circuit at the actual time to assess the real PV within the animals during CPB.

Net fluid balance in milliliters per kilogram per minute was expressed as the total amount of fluid added minus urinary output and plasma lost by bleeding over a defined period of time. The term fluid extravasation rate was defined as net fluid balance minus the change in PV during the same time interval.

\section{Statistics}

Repeated-measures analysis of variance with one within-group (time) and one between-group (CPB flow) factor was used to analyze different outcome variables. On finding a significant between-group difference or a significant interaction between the study groups, we performed the independent $t$ test to compare the groups at selected time points. If a within-group difference was found, the paired $t$ test was performed to compare the values after 60 minutes of CPB with baseline values and with the values after 150 minutes of CPB. Post-tests of net fluid balance, fluid extravasation, and PV were only performed with respect to differences between the groups.

Mean net fluid balance, urine output, fluid extravasation rate for the whole CPB period, and total tissue water content were compared by the independent $t$ test or the Mann-Whitney test.

All results are presented as mean with standard deviation in parentheses. The significance level was adjusted according to the number of multiple comparisons (Bonferroni). The analyses were conducted by the statistical software package SPSS version 13.0 for Windows (SPSS, Inc, Chicago, Ill).

\section{Results}

The HF group and the LF group were similar with respect to age, 74.0 (14.7) and 76.6 (13.8) days and weight, 29.1 (2.9) and $29.9(3.5) \mathrm{kg}$, respectively $(P>.05)$. The sex of the HF group and LF group was $5 / 3$ and $6 / 2$ (male/female). The mean prebypass cardiac output was 98.3 (22.7) and 93.4 (11.6) $\mathrm{mL} \cdot \mathrm{kg}^{-1} \cdot \mathrm{min}^{-1}$ in the HF group and LF group $(P>.05)$. Indexed values were $3.31(0.76)$ and $3.18(0.37)$ $\mathrm{L} \cdot \mathrm{m}^{-2} \cdot \mathrm{min}^{-1}$, respectively. The CPB flow rates of the HF group and LF group were $3.71(0.12) \mathrm{L} \cdot \mathrm{m}^{-2} \cdot \mathrm{min}^{-1}$ and $2.74(0.11) \mathrm{L} \cdot \mathrm{m}^{-2} \cdot \mathrm{min}^{-1}$, respectively. Body surface area (BSA) was calculated according to the formula: BSA = (Body weight $^{0.67}$ ) $\cdot$ 9/100. ${ }^{11}$

\section{Hemodynamic data, PV, and Fluid Shifts}

Mean arterial pressure (MAP) and central venous pressure (CVP) are presented in Table 1. During normothermic CPB, MAP of the LF group decreased, whereas an increase was seen in both study groups during hypothermic CPB. CVP was reduced in both study groups during normothermic $\mathrm{CPB}$ and remained unchanged during hypothermic $\mathrm{CPB}$. No significant between-group differences were present concerning MAP and CVP.

PV during CPB is presented in Figure 1, B. Before the start of bypass, PV was 52.1 (3.1) and $49.5(6.5) \mathrm{mL} \cdot \mathrm{kg}^{-1}$ in the HF group and LF group, respectively $(P>.05)$. During CPB, PV was higher in the HF group than the LF group. After 60 minutes of normothermic CPB, the values of the HF group and the LF group were 50.7 (10.4) and 39.2 (7.3) $\mathrm{mL} \cdot \mathrm{kg}^{-1}(P<.05)$.

The systemic vascular resistance index was 1382 (253) and 1704 (256) dyne $\cdot \mathrm{s} \cdot \mathrm{m}^{2} \cdot \mathrm{cm}^{-5}$ in the HF group and in the LF group after 60 minutes of normothermic CPB $(P<$ $.05)$ and $1736(408)$ and $2361(429)$ dyne $\cdot \mathrm{s} \cdot \mathrm{m}^{2} \cdot \mathrm{cm}^{-5}$ after 150 minutes of CPB $(P<.05)$.

The mean net fluid balance for the whole CPB period was $1.02(0.25)$ and $0.73(0.23) \mathrm{mL} \cdot \mathrm{kg}^{-1} \cdot \mathrm{min}^{-1}$ in the HF group and the LF group, respectively $(P<.05)$. Urine output values for the respective groups during CPB were $0.129(0.14) \mathrm{mL}$. $\mathrm{kg}^{-1} \cdot \mathrm{min}^{-1}$ and $0.019(0.013) \mathrm{mL} \cdot \mathrm{kg}^{-1} \cdot \min ^{-1}(P<.01)$.

The mean fluid extravasation rate for the CPB period was $0.98(0.22)$ and $0.77(0.22) \mathrm{mL} \cdot \mathrm{kg}^{-1} \cdot \mathrm{min}^{-1}$ in the HF group and LF group, respectively $(P=.07)$.

Figure 1 depicts the net fluid balance $(A)$ and fluid extravasation rate $(C)$ split into half-hourly periods. During the first 30 minutes after the start of CPB, the HF group had a net fluid balance of $2.38(0.92) \mathrm{mL} \cdot \mathrm{kg}^{-1} \cdot \mathrm{min}^{-1}$ and the LF group had $1.30(0.38) \mathrm{mL} \cdot \mathrm{kg}^{-1} \cdot \min ^{-1}(P<.05)$. The corresponding values for fluid extravasation rate were 2.47 (0.96) and $1.59(0.32) \mathrm{mL} \cdot \mathrm{kg}^{-1} \cdot \mathrm{min}^{-1}$ in the $\mathrm{HF}$ and $\mathrm{LF}$ groups, respectively $(P<.05)$.

\section{Laboratory Parameters and COPs}

Table 1 displays the concentrations of the laboratory parameters including COPp and COPi. During normothermic $\mathrm{CPB}$, both groups showed a significant decrease in serum albumin, serum protein, COPp, and hematocrit. The blood 
TABLE 1. Laboratory and hemodynamic parameters and core temperature during CPB with high or low CPB flow rate

\begin{tabular}{|c|c|c|c|c|}
\hline & Group & Pre-CPB & 60-min CPB & 150-min CPB \\
\hline \multirow[t]{2}{*}{ Blood glucose } & $\mathrm{HF}$ & $6.1(1.6)$ & $5.8(1.9)$ & $3.3(1.0)^{*}$ \\
\hline & $\mathrm{LF}$ & $5.6(1.5)$ & $8.2(2.9) \dagger$ & $5.9(2.3)^{*}$ \\
\hline Serum albumin & $\mathrm{LF}$ & $26.8(1.9)$ & $18.0(1.9) \ddagger$ & $16.1(1.7) \S$ \\
\hline \multirow[t]{2}{*}{ Serum protein } & $\mathrm{HF}$ & $46.1(4.4)$ & $29.9(5.3) \ddagger$ & $26.0(5.8) \uparrow$ \\
\hline & $\mathrm{LF}$ & $44.1(4.8)$ & $30.4(3.5) \ddagger$ & $27.5(3.7) \S$ \\
\hline \multirow[t]{2}{*}{$\mathrm{COPi}$} & $\mathrm{HF}$ & $7.7(2.2)$ & $5.4(1.0) \dagger$ & $3.8(0.8) \uparrow$ \\
\hline & $\mathrm{LF}$ & $7.1(1.1)$ & $6.1(0.9)$ & $4.8(0.7) \S$ \\
\hline \multirow[t]{2}{*}{ Serum osmolality } & $\mathrm{HF}$ & $285.6(4.1)$ & $283.6(2.3)$ & $282.1(3.7)$ \\
\hline & $\mathrm{LF}$ & $284.1(4.5)$ & $284.4(4.1)$ & $282.1(4.2)$ \\
\hline Hematocrit & $\mathrm{HF}$ & $31.0(2.1)$ & $22.1(1.7) \ddagger$ & $20.6(2.4)^{*}$ \\
\hline $\mathrm{PCO}_{2}$ & $\mathrm{LF}$ & $5.4(0.8)$ & $5.0(0.3)$ & $5.0(0.4)$ \\
\hline \multirow[t]{2}{*}{ Base excess } & $\mathrm{HF}$ & $5.7(1.3)$ & $3.4(1.0)^{P=.05}$ & $2.3(1.8)$ \\
\hline & $\mathrm{LF}$ & $5.0(1.0)$ & $1.5(1.8) \|$ & $0.5(1.8)$ \\
\hline \multirow[t]{2}{*}{ MAP } & $\mathrm{HF}$ & $54.1(9.2)$ & $57.0(10.3)$ & $71.1(13.4)^{*}$ \\
\hline & $\mathrm{LF}$ & $57.4(6.6)$ & $50.4(4.9) \dagger$ & $69.5(10.7) 9$ \\
\hline \multirow[t]{2}{*}{ CVP } & $\mathrm{HF}$ & $7.3(4.6)$ & $1.8(2.8) \dagger$ & $2.0(3.3)$ \\
\hline & $\mathrm{LF}$ & $3.4(2.5)$ & $0.3(2.9) \dagger$ & $-0.1(3.9)$ \\
\hline \multirow[t]{2}{*}{ Temperature } & $\mathrm{HF}$ & $37.2(0.7)$ & $38.4(0.2)$ & $28.4(0.3) \uparrow$ \\
\hline & $\mathrm{LF}$ & $37.1(1.2)$ & $38.2(0.6)$ & $28.9(0.5) \uparrow$ \\
\hline
\end{tabular}

Results as mean with $\mathrm{SD}$ in parentheses. Blood glucose $\left(\mathrm{mmol} \cdot \mathrm{L}^{-1}\right)$, serum albumin and serum protein $\left(\mathrm{g} \cdot \mathrm{L}^{-1}\right)$, colloid osmotic pressure in plasma $(\mathrm{COPp})$ $(\mathrm{mm} \mathrm{Hg})$ and in interstitial fluid $(\mathrm{COPi})(\mathrm{mm} \mathrm{Hg})$, serum osmolality $\left(\mathrm{mOsmol} \cdot \mathrm{L}^{-1}\right)$, hematocrit $(\%), \mathrm{pH}, \mathrm{PCO}_{2}(\mathrm{kPa})$, base excess $\left(\mathrm{mmol} \cdot \mathrm{L}^{-1}\right)$, mean arterial pressure $(M A P)$ and central venous pressure $(C V P)(\mathrm{mm} \mathrm{Hg})$, and rectal temperature $\left({ }^{\circ} \mathrm{C}\right)$ before $\mathrm{CPB}$ (pre-CPB) after 60 minutes of normothermic $\mathrm{CPB}$ (60-min $C P B)$ and 90 minutes of hypothermic CPB (150-min CPB). $H F$, High-flow group; $L F$, low-flow group. When possible, post-tests were performed between the values of prebypass and $60-\mathrm{min} C P B\left({ }^{*}\right.$ ) and between 60 -min CPB and 150 -min CPB $(\dagger) .{ }^{*} P<.05$ (compared with 60 -min $C P B$, same group). $\dagger P<.05$ (compared with prebypass, same group). $\ddagger P<.001 . \S P<.01 . \eta P<.001 . \| P<.01$.

sugar of the LF group was elevated. During hypothermic $\mathrm{CPB}$, the changes in serum albumin, serum protein, and COPp were sustained while blood sugars of both groups were increasing. No significant differences were found between the groups regarding the laboratory parameters.

\section{Total Tissue Water Content}

The results of total tissue water content are presented in Table 2. Total tissue water content was significantly higher in both kidneys of the HF group compared with the LF group. In the HF group, total tissue water content approached the significant level in the lungs $(P=.05)$, liver $(P=.07)$, and brain $(P=.07)$.

\section{Discussion}

Arterial pressure is a function of flow rate, blood viscosity, and vascular tone. Different strategies to elevate and maintain arterial blood pressure during CPB have previously been discussed. ${ }^{12,13}$ Elevated CPB pump flow rate resulted in improved splanchnic perfusion compared with adminis- tration of phenylephrine. ${ }^{12}$ According to statements in the literature, the disadvantage of increased pump flow during $\mathrm{CPB}$ may be the requirement of large amounts of fluid to compensate for fluid losses to the interstitial space. ${ }^{12,14}$ To our knowledge, there are no controlled studies available focusing on the relationship between different CPB flow rates and intraoperative fluid accumulation.

In the present study, we found that increasing the $\mathrm{CPB}$ flow rate from 80 to $110 \mathrm{~mL} \cdot \mathrm{kg}^{-1} \cdot \mathrm{min}^{-1}$ resulted in a more positive net fluid balance. The initial phase of CPB is known to be associated with larger fluid requirements owing to acute hemodilution. CPB flow rates seem to have a particular impact on net fluid balance and fluid extravasation rate just in this early phase. The more positive net fluid balance observed in the HF group is consistent with the tendency toward higher total tissue water values in most tissues and organs and significantly elevated levels in the kidneys. The kidney samples were taken from cortical tissue mainly consisting of glomeruli and proximal and distal 


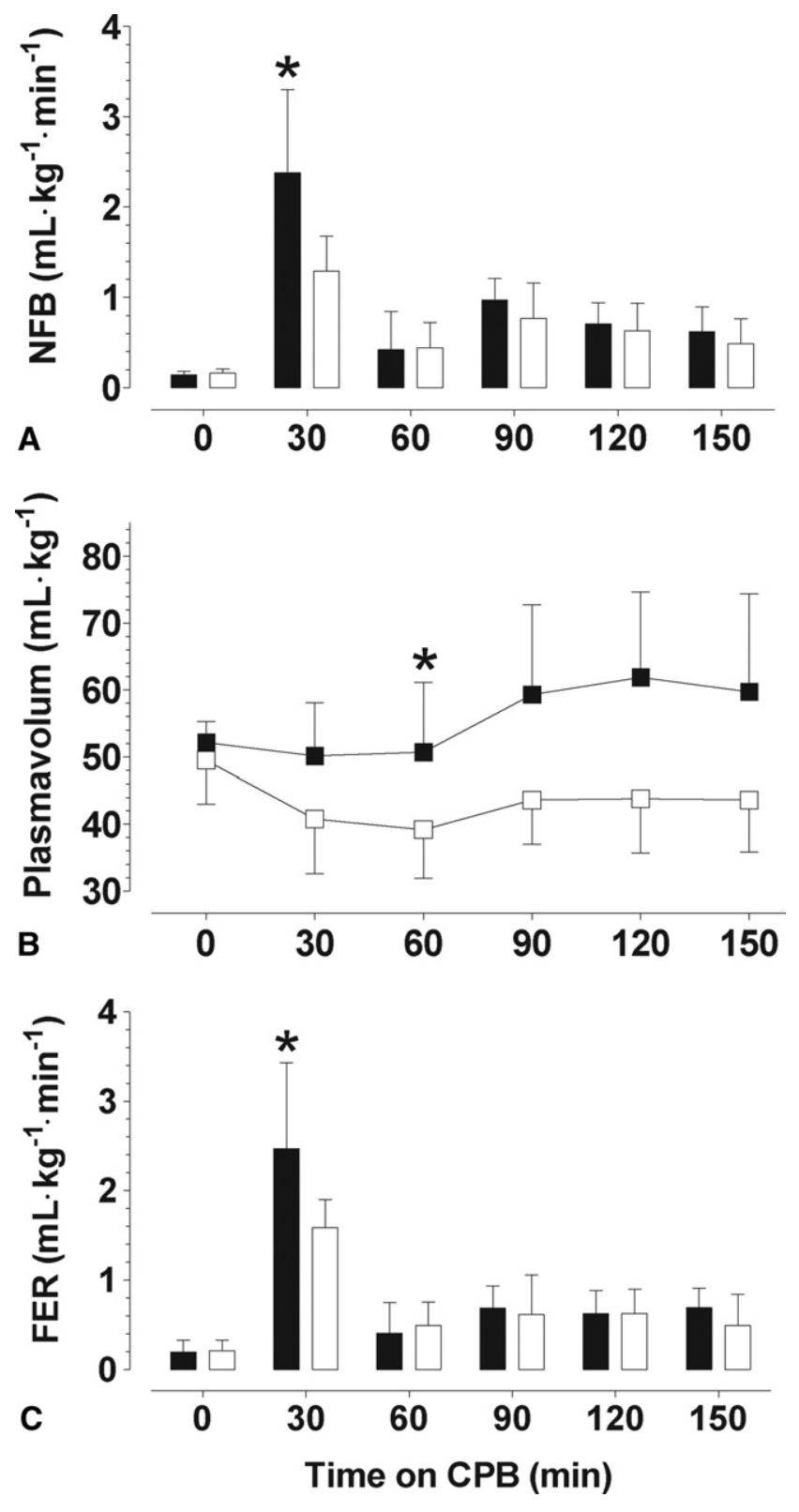

Figure 1. Net fluid balance (NFB) (A), plasma volume (B), and fluid extravasation rate (FER) (C) throughout 30-minute intervals during 60 minutes of normothermic cardiopulmonary bypass (CPB) followed by $\mathbf{9 0}$ minutes of hypothermic CPB. Solid black columns and squares, High-flow group. White columns and squares, Lowflow group. The values are as mean $\pm S D$. ${ }^{*} P<.05$ (betweengroup comparison).

tubuli. The average urine output was more than 6 times higher in the HF group, suggesting a physiologic response to higher PV in this group. The elevated total tissue water may reflect increased glomerular filtration and a higher amount of fluid in the tubular system. The level of atrial
TABLE 2. Total tissue water content

\begin{tabular}{lcc}
\hline & HF group & LF group \\
\hline Left myocardium & $4.15(0.11)$ & $4.13(0.12)$ \\
Right myocardium & $4.69(0.22)$ & $4.75(0.57)$ \\
Lung & $6.51(1.14)$ & $5.45(0.83)(P=.05)$ \\
Stomach (muscularis) & $5.84(0.54)$ & $5.54(0.45)$ \\
Stomach (mucosa) & $5.73(0.89)$ & $5.47(0.74)$ \\
lleum (muscularis) & $5.91(0.99)$ & $5.80(0.97)$ \\
lleum (mucosa) & $7.04(2.11)$ & $6.83(1.26)$ \\
Colon & $6.96(2.50)$ & $7.50(2.64)$ \\
Liver & $3.62(0.18)$ & $3.47(0.12)$ \\
Pancreas & $5.42(1.18)$ & $5.68(1.29)$ \\
Left kidney & $5.04(0.23)$ & $4.62(0.25)^{*}$ \\
Right kidney & $5.20(0.37)$ & $4.73(0.33) \dagger$ \\
Skin & $2.85(0.54)$ & $2.42(0.46)$ \\
Skeletal muscle & $4.27(0.50)$ & $4.06(0.23)$ \\
Brain & $4.14(0.21)$ & $3.95(0.19)$ \\
\hline
\end{tabular}

Results as mean with SD in parentheses. Total tissue water content $(\mathrm{g} \cdot \mathrm{g}$ dry weight ${ }^{-1}$ ) of tissue from the high-flow group (HF group) and the low-flow group (LF group). ${ }^{*} P<.01 . \dagger P<.05$ (between-group differences).

natriuretic peptide is known to increase during $\mathrm{CPB} .{ }^{15,16}$ The relationship between elevated levels and the amount of intraoperative urine output is not clear. ${ }^{16}$ Unfortunately, atrial natriuretic peptide was not measured in the present study.

Serum glucose increased during normothermic CPB in the LF group, whereas it remained unchanged in the HP group. The slightly hyperglycemic level of the LF group may be related to an activation of the sympathetic nervous system, as also suggested by the lower intravascular volume in this group. During hypothermic CPB, however, serum glucose decreased in both groups compared with normothermic CPB.

Fluid shifts across the capillary membrane are determined by the factors of the Starling equation. ${ }^{17}$ The consequences of larger PVs with a tendency toward lower COPp values may have contributed to more pronounced fluid extravasation in the HF group during normothermic CPB.

The capillary hydrostatic pressure is basically determined by the arterial and venous pressures and the precapillary/postcapillary resistance ratio. ${ }^{18}$ Systemic vascular resistance was higher in the LF group, suggesting that the precapillary/postcapillary resistance ratio was higher than in the HF group. During normothermic CPB, there was a trend to differences in the arterial pressure between the two study groups. This may also have contributed to the more positive fluid balance in the HF group during normothermic CPB by increasing the capillary hydrostatic pressure.

During stable normothermic and hypothermic CPB, the fluid balance stabilized and different flow rates did not seem to influence the result. After the initial phase of CPB, filtration was opposed by the simultaneous reduction in 
COPi (Table1) resulting from a wash-down effect on interstitial proteins. ${ }^{19}$ Another factor counteracting capillary filtration could be a gradual elevation of the interstitial hydrostatic pressure. This was not assessed in the present study but has been described by others in clinical studies with CPB. ${ }^{20,21}$

CPB with elevated flow rate depends on adequate venous drainage. In the present study, the venous drainage was monitored by visual inspection and by right atrial pressure recordings. A small, nonsignificant trend to higher CVPs was found in the HF group. Conceivably, this could have influenced the results. However, the tendency to higher CVP in the HF group was present even before CPB. Besides, inadequate venous drainage would be expected to cause higher fluid accumulation throughout the experiments, whereas the observed difference was seen only during the hemodilution phase.

Another limitation of the present study could be the use of higher CPB flow rates than those commonly applied in clinical practice. However, cardiac index of domestic pigs is about twice the normal values of humans. ${ }^{22}$ The currently used CPB flow rate of $2.4 \mathrm{~mL} \cdot \mathrm{m}^{-2} \cdot \mathrm{min}^{-1}$ in humans corresponds with values of cardiac index in anesthetized humans. ${ }^{23}$ In the present study, CPB flow rate was set about $15 \%$ above and below the prebypass values. Accordingly, the findings from the first 60 minutes of CPB should be relevant for clinical practice with the use of normothermic CPB in older children and adults. During hypothermic CPB, flow was not reduced and consequently both groups were subjected to some degree of hyperperfusion. However, our main purpose was to study the specific effects of different flow rates on fluid shifts rather than providing optimal oxygen supply to the body. We therefore considered this to be an acceptable limitation.

Fluid accumulation during CPB is well tolerated by the majority of patients, but increased age and comorbidity may render the current patient population more vulnerable. ${ }^{24}$ Experimental studies have shown that myocardial edema may lead to systolic and diastolic dysfunction. ${ }^{25}$ The individual patient should have the CPB flow rate adjusted according to needs. Although the etiology of fluid accumulation is multifactorial, the use of unnecessarily high flow rates may contribute to postoperative fluid accumulation with possible effects on organ function.

\section{Conclusions}

In this animal model, elevation of CPB flow rate was associated with a more positive intraoperative fluid balance and an increase in fluid extravasation rate. The effect was predominantly seen in the initial phase of CPB.

The board of the Faculty of Medicine, University of Bergen, has authorized the "Locus for Circulatory Research" as an officially recognized research group within the faculty. We greatly acknowl- edge this support. The technical assistance of Arve Mongstad (RP), Else Nygreen (RP), Lill Andreassen, Gry Hilde Nilsen, and Cato Johnsen is greatly appreciated. Oddbjørn Haugen is a research fellow of the Western Norway Regional Health Authority, Stavanger, Norway.

\section{References}

1. Toraman F, Evrenkaya S, Yuce M, Turek O, Aksoy N, Karabulut H, et al. Highly positive intraoperative fluid balance during cardiac surgery is associated with adverse outcome. Perfusion. 2004;19:85-91.

2. Schroth M, Plank C, Meißner U, Eberle K-P, Weyand M, Cesnjevar R, et al. Hypertonic-hyperoncotic solutions improve cardiac function in children after open-heart surgery. Pediatrics. 2006;118:e76-84.

3. Luciani GB, Menon T, Vecchi B, Auriemma S, Mazzucco A. Modified ultrafiltration reduces morbidity after adult cardiac operations. Circulation. 2001;104(Suppl I):I253-9.

4. Farstad M, Heltne JK, Rynning SE, Lund T, Mongstad A, Eliassen F, et al. Fluid extravasation during cardiopulmonary bypass in pigletseffects of hypothermia and different cooling protocols. Acta Anaesthesiol Scand. 2003;47:397-406.

5. Farstad M, Kvalheim VL, Husby P. Cold-induced fluid extravasation during cardiopulmonary bypass in piglets can be counteracted by use of iso-oncotic prime. J Thorac Cardiovasc Surg. 2005;130:287-94.

6. Farstad M, Heltne JK, Rynning SE, Onarheim H, Mongstad A, Eliassen $\mathrm{F}$, et al. Can the use of methylprednisolon, vitamin $\mathrm{C}$, or $\alpha$-trinositol prevent cold-induced fluid extravasation during cardiopulmonary bypass in piglets? J Thorac Cardiovasc Surg. 2004;127:525-34.

7. Husby P, Heltne JK, Koller ME, Birkeland S, Westby J, Fosse R, et al. Midazolam-fentanyl-isoflurane anaesthesia is suitable for haemodynamic and fluid balance studies in pigs. Lab Anim. 1998;32:316-23.

8. Haugen O, Farstad M, Kvalheim VL, Rynning SE, Hammersborg S, Mongstad A, et al. Mean arterial pressure about $40 \mathrm{mmHg}$ during CPB is associated with cerebral ischemia in piglets. Scand Cardiovasc J. 2006;40:54-61.

9. Heltne JK, Husby P, Koller ME, Lund T. Sampling of interstitial fluid and measurement of colloid osmotic pressure $\left(\mathrm{COP}_{\mathrm{i}}\right)$ in pigs: evaluation of the Wick method. Lab Anim. 1998;32:439-45.

10. Heltne JK, Farstad M, Lund T, Koller ME, Matre K, Rynning SE, et al. Determination of plasma volume in anesthetized piglets using the carbon monoxide (CO) method. Lab Anim. 2002;36:344-50.

11. Hawk CT, Leary SL. Formulatory for laboratory animals. American College for Laboratory Animal Medicine, Iowa State Pr (Sd). 1995. p. 78

12. O'Dwyer C, Woodson LC, Conroy BP, Lin CY, Deyo DJ, Uchida T, et al. Regional perfusion abnormalities with phenylephrine during normothermic bypass. Ann Thorac Surg. 1997;63:728-35.

13. Plochl W, Orszulak TA, Cook DJ, Sarpal RS, Dickerman DL. Support of mean arterial pressure during tepid cardiopulmonary bypass: effects of phenylephrine and pump flow on systemic oxygen supply and demand. J Cardiothorac Vasc Anesth. 1999;13:441-5.

14. DiNardo JA, Wegner JA. Pro: low-flow cardiopulmonary bypass is the preferred technique for patients undergoing cardiac surgical procedures. J Cardiothorac Vasc Anesth. 2001;15:649-51.

15. Lehot JJ, Villard J, Piriz H, Philbin DM, Carry PY, Gauquelin G, et al Hemodynamic and hormonal responses to hypothermic and normothermic cardiopulmonary bypass. J Cardiothorac Vasc Anesth. 1992;6:132-9.

16. Brancaccio G, Michielon G, Di Donato RM, Costa D, Falzea F, Miraldi F. Atrial natriuretic factor in normothermic and hypothermic cardiopulmonary bypass. Perfusion. 2004;19:157-62.

17. Starling EH. On the absorbtion of fluids from the connective tissue spaces. J Physiol. 1896;19:312-26.

18. Maspers M, Björnberg J, Mellander S. Relation between capillary pressure and vascular tone over the range from maximum dilatation to maximum constriction in cat skeletal muscle. Acta Physiol Scand. 1990;140:73-83.

19. Levick JR. Circulation of fluid between plasma, interstitium and lymph: In: Levick JR, editor. An introduction to cardiovascular physiology, 4th ed. London: Arnold; 2003. p. 171-98. 
20. Rein KA, Stenseth R, Myhre HO, Levang OW, Kahn S. Time-related changes in the Starling forces following extracorporeal circulation. Cardiovasc Drugs Ther. 1988;2:561-8.

21. Menninger FJ 3rd, Rosenkranz ER, Utley JR, Dembitsky WP, Hargens AR, Peters RM. Interstitial hydrostatic pressures in patients undergoing CABG and valve replacement. J Thorac Cardiovasc Surg. 1980;79:181-7.

22. Hannon JP, Bossone CA, Wade CE. Normal physiological values for conscious pigs used in biomedical research. Lab Anim Sci. 1990;40:293-8.
23. Cook DDJ. Con: low-flow cardiopulmonary bypass is not the preferred technique for patients undergoing cardiac surgical procedures. J Cardiothorac Vasc Anesth. 2001;15:652-4.

24. Horan PG, Leonard N, Herity NA. Progressively increasing operative risk among patients referred for coronary artery bypass surgery. Ulster Med J. 2006;75:136-40.

25. Geissler HJ, Allen SJ. Myocardial fluid balance: pathophysiology and clinical implications. J Thorac Cardiovasc Surg. 1998;46:242-5.

\section{ON THE MOVE?}

Send us your new address at least six weeks ahead

Don't miss a single issue of the journal! To ensure prompt service when you change your address, please photocopy and complete the form below.

Please send your change of address notification at least six weeks before your move to ensure continued service. We regret we cannot guarantee replacement of issues missed due to late notification.

\section{JOURNAL TITLE:}

Fill in the title of the journal here.

\section{OLD ADDRESS:}

Affix the address label from a recent issue of the journal here.

\section{NEW ADDRESS:}

Clearly print your new address here.

Name

Address

City/State/ZIP
COPY AND MAIL THIS FORM TO:

Elsevier Inc.

Subscription Customer Service

6277 Sea Harbor Dr

Orlando, FL 32887
OR FAX TO:

407-363-9661

OR E-mail:

elspcs@elsevier.com
OR PHONE:

800-654-2452

Outside the U.S., call

407-345-4000 